\title{
Microgrids Technology: A Review Paper
}

\author{
${ }^{1}$ Abhishek Kumar, ${ }^{2}$ Muhammad Zafar Ullah Khan, ${ }^{3}$ D. M. Akbar Hussain \\ ${ }^{1}$ SET, Sharda University, India, \\ ${ }^{2}$ University of Management \& Technology, Sialkot Campus, Pakistan, \\ ${ }^{3}$ Aalborg University, Denmark \\ abhishekmth97@gmail.com, 22acd.dir@skt.umt.edu.pk 33akh@et.aau.dk
}

\begin{abstract}
Microgrids are currently rising centres, banks and pilot exhibition locales in business markets, driven by mechanical enhancements, diminishing costs, demonstrated involvement and developing acknowledgement of their advantages. They are utilised to enhance the dependability and strength of intensity frames, to deal with the expansion of conveyed clean vitality assets, for example, wind and sunlight based age to lessen petroleum derivative emanations and to give power in territories that are not don't have incorporated electrical framework. This survey provides a multidisciplinary representation of current microgrid controllers, specific applications, difficulties and prospects.
\end{abstract}

Keywords-Microgrids, Renewable integration Prosumers, Distribution energy

\section{INTRODUCTION}

In recent times, it is shown that the world's electrical frameworks are starting to "reorganise, decarbonise and democratise", much of the time from the beginning [1]. These patterns, otherwise called the "Three Ds", are spurred by the need to control power costs, supplant out of date foundation, enhance strength and dependability, lessen $\mathrm{CO} 2$ discharges, and to give substantial power. Regions that need electrical foundation. While the harmony amongst drivers and the points of interest of the specific arrangement may contrast from place to put, small microgrids have turned into adaptable engineering for sending conveyed vitality assets (DER) that can happen the expansive needs of various networks from the New-York metropolitan territory to provincial India. In developed nations, Microgrid frameworks should be analysed with regards to a build microgrid that incorporates gigawatt creating units, thousands or even a considerable number of high-voltage transmission lines, least vitality stockpiling, and energises. Fossils. Carbon as a wellspring of essential dynamism. Nonetheless, the present grids is definitely not a static substance; We are experiencing a notable circular segment that began with a little-appropriated circulation (perceived as the first DC miniaturized scale systems) propelled by Thomas Edison toward the finish of the nineteenth century, which has seen solidification and centralization driven by expanding request, and is currently encountering the beginnings of an arrival to reorganisation. From the 1920s to the 1970s, the best dependability offered by associate numerous creation units to various burdens, diminish development costs per kilowatt $(\mathrm{kW})$ and the capacity to remove vitality from huge, far off age assets, for example, the hydroelectric power that prompted the improvement of the network we see today [3] 4]. In any case, these advantages appear to have achieved their points of confinement and are progressively undermined by natural and financial concerns.

Driven by the rebuilding of open administrations, the change of DER innovations and the monetary dangers that go with the development of enormous transport framework and generation offices, organisations that deliver power have been steadily exchanged to all the more little-decentralised units of time [3]. This progress is spurred by a scope of DER benefits that have been considered in detail; 
$[2,4,5]$, as the deferral of interests underway, transmission and dissemination limits; voltage control or VAR (receptive power), helper administrations, natural advantages of emanations, lessening of framework misfortunes, influence age investment funds, enhanced unwavering quality, change of vitality quality, cogeneration, diminishment of interest and reservation age. These mines are significantly littler than non-renewable energy source plants, a considerable lot of which additionally bolster the sending of discontinuous sustainable age sources, as shown by an establishing investigation of a $500 \mathrm{~kW}$ photovoltaic plant disseminated in California [6,7]. The test of definitely decreasing ozonedepleting substance outflows to keep a disastrous atmosphere interruption has likewise influenced government strategies that energise the arrangement of without carbon wellsprings of generation, a considerable lot of which are agreeable to appropriated applications. While this paper centres around small-scale matrices in regions with existing incorporated power frameworks recall that they likewise have numerous advantages for rural and remote networks in creating nations; These are shrouded in more detail underneath. Beginning in the late 1990s, as portrayed in Section 1.2, US and European researchers and specialists started to investigate decentralised arrangements that can deal with the combination of thousands or many disseminated vitality assets. It additionally augments dependability and strength notwithstanding catastrophic events, physical and digital assaults, and falling force blackouts. The arrangement they built up was a system design equipped for overseeing power age and request locally in subsections of the system that could be consequently disconnected from the more important system to give necessary administrations notwithstanding when the worldwide network is coming up short. This approach has been called "Microgrid".

Table 1. Overview of Microgrid Generation \& Storage Option

\begin{tabular}{|c|c|c|c|}
\hline carcegox & & Advantages & Disadvantages \\
\hline Generation & 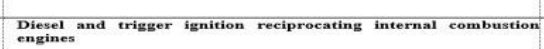 & & \\
\hline & {$[6]$} & - Quick startup & emistions \\
\hline & & 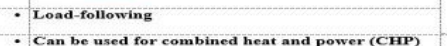 & Creenhouse Gas Emissions \\
\hline & Microturbines [7] & - Dispatchable & $\begin{array}{l}- \text { Noise generation } \\
- \text { Greenhouse Gas Emissions }\end{array}$ \\
\hline & & 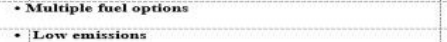 & \\
\hline & & - Mechanical simplicity & \\
\hline & Fuel cells (including solid oxide, motten-carbonate, phosphorici & - CHP-capable & \\
\hline & 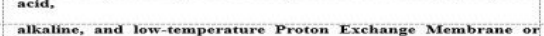 & $\cdot$ - Dispachable & - Relatativaly expensive \\
\hline & PEAT & - Zero on-site pollution & - Limited lifetime \\
\hline & & - Higher effictency avaitible versus mieroturbines & \\
\hline & $\begin{array}{l}\text { Renewable Generation (solar photovoltaic cells, small wind } \\
\text { turbiness, and mini-hydro) }\end{array}$ & $\begin{array}{l}\text { Zero fuel cost } \\
\text { Zero emissions }\end{array}$ & $\begin{array}{l}\text { - Not dstsanchable without } \\
\text { strorage }\end{array}$ \\
\hline Storage & Batteries (including lead acid, sodium-salfux, Hithium ton, and & - Long history of research and development & $\begin{array}{l}\text {-. Limited number of charge- } \\
\end{array}$ \\
\hline & nickel cadmium) [9] & & discharge cycles \\
\hline & "Flow batteries", also kenov as "regenerative fuel cells" (including & - Decouple power and energy storage [11] & Relatively early stage of \\
\hline & zinc-bromine, polysulphide bromide, vanadium redox) [8] & - Able to support continuous operation at maximum & deployment \\
\hline & Hydrogen from hydrolysis [11] & $\begin{array}{l}\text {. Tlean and complete discharge without risk or damage } \\
\text { Clean }\end{array}$ & - Relatively low end-to-end \\
\hline & & & . efticiency \\
\hline & Kinetic energy storage (n,ywheels) $[8,9]$ & Fast response & • Limitted discharge time \\
\hline & & - High charge- discharge cycles & - High standing losses \\
\hline & & - High efficiency & \\
\hline
\end{tabular}

\section{WHAT IS MICROGRIDS}

A microgrid is a little or neighbourhood control framework that is free of the mass supply arrange. For instance, it might be a consolidated warmth and power framework in light of a gaseous petrol ignition motor (which co-produces power and high temp water or water vapour used to cold the flammable gas turbine) or diesel, sustainable power source or batteries. Fuel. Microgrids based sub-stations could be utilised as a part of the better path at server farms, colleges, healing centres, production lines, army 
installations or entire networks (i.e. "Town Power"). (Campbell 2012) A more brief meaning of the Microgrid Conversation Group1. It ought to be noticed that assessments contrast on the general generation limit that ought to be contained in the Microrred's capacity framework and that there ought to be just a single regular purpose of coupling with the principle organise or various purposes of coupling. (Ye, et al., 2005) For the island idea to work, the Microrred must be confined from the primary system, either by at least one disengage focuses. As per Microgrids and Sandy's Super Storm report, a plant administrator noticed that "a genuine small-scale arrange significantly more than a reinforcement control framework, yet in addition since one of its essential capacities incorporates continuous on location controls to coordinate the age and size limit of the Microgrid for the utilization of ongoing vitality and communicate with the system. (St. John 2012). [1]

As per the sources inspected for this report, Microgrid incorporates the following key highlights:

1. task in both island mode or grids associated

2. introduction to the Microgrid as a solitary controlled element

3. mix of interconnected burdens and co-found power age sources

4. arrangement of fluctuated stages of intensity quality \& unwavering quality for end-clients, intended to oblige add up to framework vitality prerequisites

An Elementary microgrid architecture is shown below in Fig. 1

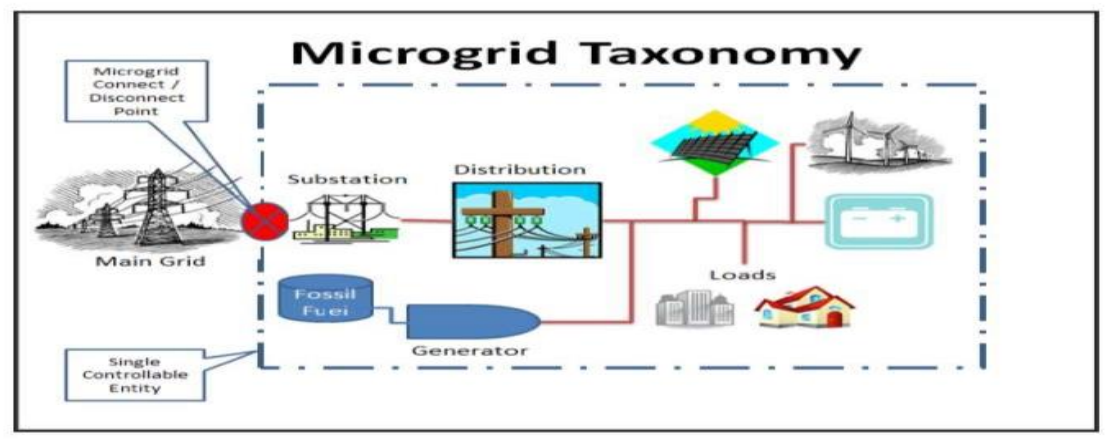

Fig. 1. Elementary Microgrid Architecture.[1]

\section{MICROGRID ARCHITECTURE}

A Microgrds may contain a part of the MV/LV conveyance frameworks and the gathered burdens served by an individual or different DER. From the perspective of the task, a miniaturised scale framework can work with a typical association direct (PCC) toward whatever is left of the power grids of the district and additionally exchange without issues between two conditions of the associated organise and a detached system mode ( IG). At the point when physically associated with the fundamental system, the method of activity and control of the small-scale system can change between a low system mode (GD) or a grids free mode (GI) (self-ruling mode) contingent upon the system. Vitality trade and the connection of the small-scale network with the spine framework [4]. Smaller scale wellsprings especially notable are little units (greater than $100 \mathrm{~kW}$ ) for Micro Grids with electronic power boundaries. These causes (normally microturbines, photovoltaic boards and power devices) are set on client destinations. They are comfortable, low voltage and have consistently high quality with low discharges. Power hardware gives the control and adaptability required by the microarray idea. Very much composed commands and power hardware guarantee that the Micro-Network can address the issues of its clients and administrations [2]. Smaller scale systems comprise of a few fundamental working advancements, for example, DG, DS, and control framework. Expanded consistent quality, proficiency, and security of the power framework. Empower decentralised vitality age so families can be the two clients and providers of vitality (furnishing customers with an inventive apparatus for overseeing vitality utilisation). The adaptability of client-side power utilisation to empower provider choice (Enables decentralised age) [4]. Increment GDP by making more occupations identified with the 


\section{Gyancity Journal of Electronics and Computer Science \\ Vol.3, No.1, pp. 11-23, March 2018 \\ ISSN:2446-2918 DOI: 10.21058/gjecs.2018.31002}

vitality business in mechanical assembling, pluggable electric vehicles, sun based board and wind turbine generation, and in the data innovation industry. Empower edified client interest

1. Adapt all age and capacity alternatives

2. Allow new items, administrations and markets

3. Provide vitality quality for the scope of necessities of the advanced economy

4. Optimize the utilisation of benefits and capacity adequately

5. Deal with unsettling influences and rebuilding efforts

6. Work hard against all perils

These objectives can be accomplished by embracing the most recent advances to guarantee achievement while holding the adaptability to adjust to future improvements. Advances in correspondence, estimation and commercial frameworks will expose new open doors at all levels of the structure to empower advertise signs to drive specialised and business efficiency. [3].

\section{COMPONENTS OF MICROGRID}

To meet the usefulness and operational necessities specified over, an assortment of segments are fundamental for microgrid activity. These advances are fundamentally a mix of Distributed Energy Resources (DER), which might be a Distributed Generation Unit (DG), Distributed Storage (DS) or an Active Load. Also, a physical system to associate them all, and a third propelled request checking and reaction innovation, to work and control the dissemination of vitality streams and give data on vitality utilise.The charge (s) of a Microgrids are the parts that expend power, for example, water warmers, aeration and cooling systems, iceboxes, and so forth. These charges require power at various circumstances of the day, contingent upon use. In a perfect world, these charges ought to have the capacity to be controlled with some arbitrary limit when utilised, to provide further adaptability in altering interest to supply. Also, since the smaller scale system can serve an assortment of private, business and modern clients, stack arrangement is critical to accomplishing the operational technique for:

1. See the net weight/send out power in framework associated mode and balance out voltage and recurrence in island mode by encouraging burden/age shedding.

2. Enhance control quality and consistent quality of primary and delicate burdens (business and mechanical clients).

3. Lessen the pinnacle capacity to improve the DER evaluations [11].

Decentralized creation units outline the start of microgrids, which give the power anticipated that would address the issues of the buyer. In addition, as the goal is to pass on more viable and cleaner essentialness creation over the principal frameworks, economical (non-controllable) on area age decisions join sun based photovoltaic (PV) and microwave ( $<\mathrm{MW})$, control modules and microelectronic hydropower, regardless of the way that the latter is a confined territory advancement. Standard yet controllable high-capability DG options join internal start engines, diesel generators and cogeneration plants under $50 \mathrm{MW}$, which can be energised by secretly conveyed biomass or methane instead of oil gas. a cleaning decision $[4,11,10]$. To the extent DG scale, they appear, all in all, to be in the extent of kW instead of MW [8]. As demonstrated by [4] a microgrid must have no less than one [6]. Controllable DG units to extend the versatility and trustworthiness of the power. Also, it has been discovered that a couple of humbler DGs are better at customised stack following, like this upgrading imperativeness security [12]. Coursed storing choices are essential for a microgrid because DG control age can't be immaculately organised to stack demands. Along these lines, DS upgrades the general execution of the microgrid by going about as a framework to meet its ability and power essentials. These limit choices consolidate creative decisions, for instance, batteries, flywheels, control condensers, compacted air and pumped hydro limit, or low advancement plans, for instance, cool water or ice storing. Electric vehicles (EVs) are furthermore seen as a possibility for securing imperativeness 


\section{Gyancity Journal of Electronics and Computer Science}

Vol.3, No.1, pp. 11-23, March 2018

ISSN:2446-2918 DOI: 10.21058/gjecs.2018.31002

amid the night when asking for and the cost of intensity is low. These limit decisions settle and empower DG units to work reliably, notwithstanding load instabilities. This mitigates the brokenness of maintainable fundamental imperativeness sources, for instance, the sun and the breeze, and empowers the DG to work clearly as distributable units to give additional power on ask for $[4,1]$.

The robust framework that scatters control between DG units, DS units, loads, and the key frame is the essential layer of the power structure, which relates all the fundamental parts. Weights are given by advantage connections or connections that connect customers with their DER and rule mastermind from a low voltage (LV) distributer. It is an aeronautical improvement (open relationships made of pottery or designed encasings) or underground (canvassed joins or in a channel) [12]. Finally, the LV sends are related with a central course station by methods for an interconnection switch, which is the fundamental issue of coupling (CCP) where synchronisation with the essential medium voltage orchestrate happens. This framework ends up enlivened and fills in as a course facilitates the usage of ingenious electronic contraptions (IEDs). These are p. Automated circuit breakers and security exchanges to guarantee work power and rigging in the midst of disillusionment, remote-controlled switches, current and voltage sensors, and status checking units for switches and transformers [13, 14, 10]. To viably work and control DG units with DS units and controllable weights, advanced electronic essentialness control and change limits are required to fuse correspondence between all parts in a sorted out little scale group organisation structure. This may resemble the present scattering organisation structure revived with BT motorisation [13]. This requires particular hardware and programming control systems, for instance, propelled protection exchanges, to quickly perceive, withdraw, and repair blemishes. If a DC DER is used, for example, a sun arranged age or batteries, an inverter interface is primary to change over DC respect AC at the appropriate voltage level. Microgrids architecture is appeared beneath in figure 2. [14-20]

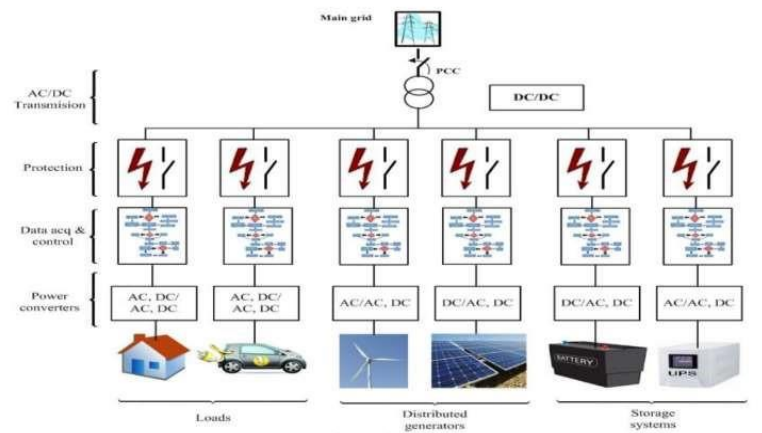

Fig. 2. The architecture of Microgrids.[17]]

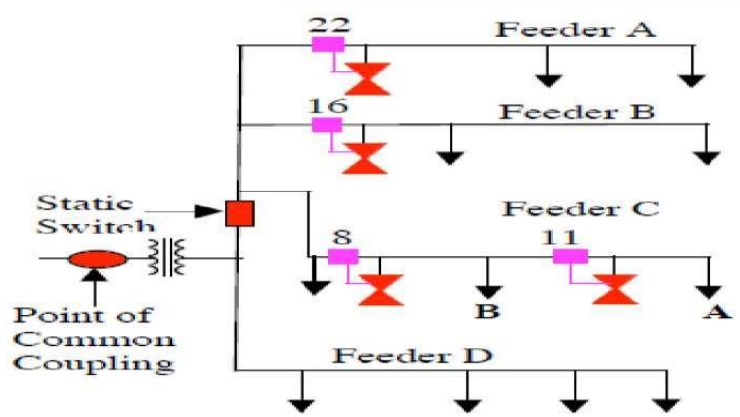

Fig. 3. Microgrids [38]

\section{MICROGRIDS STATION}

Albeit much has been composed about the idea and guarantee of the microgrid, we can likewise learn numerous cases of genuine and operational smaller scale systems. For a thorough rundown of existing, test and reenacted tiny frameworks, perusers are encouraged to counsel an ongoing survey by Mariam et al. (2016) in this magazine. As per Navigant Research, which has followed miniaturised scale cluster sending since 2011, The USA has been the noteworthy pioneer in conveyed abilities; today, in any case, the United States and Asia generally have a similar ability to work, creating and offering smaller scale matrices, all with $42 \%$ of the market. Whereas $11 \%$ remains in Europe, and Latin America at $4 \%$ and the Middle East and Africa at just 1\%. Add up to limit was around $1.4 \mathrm{GW}$ in 2015 and is required to reach around $5.7 \mathrm{GW}$ (preservationist appraise) or $8.7 \mathrm{GW}$ ("forceful" situation) by 2024. Navigant breaks the Microgrids showcase in the accompanying fragments (with the $\%$ of the aggregate power conveyed in the primary quarter of 2016): far off (54\%), business/mechanical (5\%), network (13\%), dispersion of open administrations (13\%), institutional/grounds (9\%) and military (6\%) [36]. It ought to be noticed that Navigant Research does not take after remote smaller scale cluster frameworks 


\section{Gyancity Journal of Electronics and Computer Science \\ Vol.3, No.1, pp. 11-23, March 2018 \\ ISSN:2446-2918 DOI: 10.21058/gjecs.2018.31002}

construct only concerning diesel generators; to be considered, they should incorporate no less than one sustainable wellspring of creation. Even though it isn't conceivable here to introduce a thorough depiction of the unique uses of microgrids, we will feature some of them below.[38]

\section{A. Campus/Institutional:}

The usage of on location generation, especially in the consolidated uses of refrigeration, warmth, and vitality (CCHP, additionally called "trigeneration") with numerous charges set on a grounds having a place with a single substance, has been an effective model as of not long ago. It incorporates the biggest miniaturised scale matrices to date, with limits extending from 4 to more than $40 \mathrm{MW}$. Santa Clause Rita Jail, situated in Alameda County, California, is a genuine institutional microgrid test utilising the CERTS idea. The miniaturized scale grids includes a $1 \mathrm{MW}$ energy component, $1.2 \mathrm{MW}$ of sunlight based photovoltaic vitality, two 1.2 MW diesel generators and a $2 \mathrm{MW} / 4 \mathrm{MWh}$ electric iron phosphate stockpiling framework (picked on the grounds that that this compound has a high AC-AC execution and offers enhanced warm and concoction solidness contrasted with other battery advancements, in spite of some absence of vitality thickness), a quick static disengage and a battery redress factor Power Capacitors The CERTS convention permitted these appropriated control assets to cooperate among system and island associated modes without the requirement for a custom focal controller. The limit of an institutional miniaturised scale system to give most extreme load lessening. Business trades between advancing the type of the net load for the establishment and the necessities of the system have been shown utilising Santa Rita Jail, for instance, utilising the DER-CAM programming to decide to the program and sending ideal hardware. [25] [38-43].

\section{B. Military microgrids:}

Economically smart imperativeness security, "the limit of a foundation to get to a tried and true supply of intensity and fuel and the best approach to use them to guarantee and offer satisfactory to meet the savants in the midst of a drawn-out obstruction of the arrangement of neighborhood control 'is the basic controller of military microgrid related with the framework (in like manner made responses for the operational utilization organize). A not too bad instance of military microgrid research and indicating tries is the display of establishment Intelligent Energy Reliability and Energy Security (SPIDERS) Demonstration of Common Capability Technologies (JCTD), a three-phase, scope and the growing flightiness with each stage. Dispose of 1 was passed on in the Pearl Harbor-Hickam, Hawaii joint base in 2012 and 2013 with a single power dissemination contraption, two electrically isolated weights, generators and VP two diesel matrix. Stage 2 happened in 2013 and 2014 in Fort Carson, Colorado and fused three scattering lines of seven improvement loads, three diesel generators, a $1 \mathrm{MW}$ photovoltaic generator and five bi-directional electric vehicle chargers. The last stage 3, at Camp Smith, Hawaii, was done toward the completion of 2015; used new and existing age sources to help stores of the entire base. A more quick and dirty delineation of the bugs, including the mechanical security parts of the errand, and connections with other military microgrid es are open in writing.[21-23] [2730].

\section{Residential:}

The subject of the ideal accumulation scale is an open inquiry in the microgrid writing and a functioning territory of research. For instance, is it better to coordinate free private clients into large network smaller microgrids or to execute microgrid innovation at the individual family unit level? The advantages of a completely decentralized coordinated system approach incorporate the control of vitality assets by the clients and the way that the different houses are as of now associated with the power conveyance organize, so any progressions made behind the counter administrations to include smaller scale framework capacities without lawful or administrative difficulties past what has just been found for the interconnection of housetop sunlight based establishments at introduce. In the meantime, this approach, mainly if it incorporates island limit, for economies of scale cost investment funds and the age and 


\section{Gyancity Journal of Electronics and Computer Science \\ Vol.3, No.1, pp. 11-23, March 2018 \\ ISSN:2446-2918 DOI: 10.21058/gjecs.2018.31002}

decent variety of the heap that accompanies the systems administration of different generators and burdens. For instance, the cost of interconnection security can be up to half of the value of a miniaturised scale source (i.e. serving an individual task or a little building). It might in this manner be smarter to put many assets behind the utility interface. A few creators imagine a settled framework in which building-level vitality administration frameworks speak with each other and with neighbourhood drivers to facilitate appropriated vitality assets, including shared network vitality assets and loads, for example, open lighting. The building-coordinated microgrid usage model would almost certainly advantage from creative financing (like sun oriented renting models) because of asset creation costs, controllers, control hardware and joining with control plants. Existing building frameworks. The writing that investigates supposed "client small-scale systems" looks at the specialised attainability and financial reasonability of this expansive, decentralised private sending model. A large number of these examinations are propelled by the topic of whether it is plausible or potentially attractive to accomplish full power framework self-governance using PV and battery stockpiling. An appealing private microgrid application joins industrially accessible onnetwork housetop photovoltaic frameworks, cheap chargers for electric vehicles (EV) and vitality storing structures (ESS) at home or in the house. Neighbourhood. Among the day, The PV will be charged nearby ESS, and among the night it will be moved to the EV. The impact is two-crease:

1.Feed-in tariff plans are a bit much since little power should be traded with the first framework,

2.Voltage quality at the PCC is moved forward.

The ESS interconnection reduces overvoltages among the day because of abundance PV control age \& under voltages among the night produced by the large current depleted to control the vehicle.[20-30]

\section{Remote and rural microgrids:}

More than a billion people in creating and immature nations at present have no dependable access to power or power. Frequently, the constrained power accessible is delivered utilising costly diesel fuel. Specifically, in rural regions of these nations, power is a significant asset for conference essential social needs, and miniaturised microgrids might be the ideal approach to give this power. Remote small scale organises that consolidate clean generation and capacity, once in a while encouraged by creative, versatile instalment stages, can give a lifesaver to these individuals, enabling kids to learn around evening time, dependable medicinal frameworks and business people to enhance their lives. the methods forever. These remote small-scale systems advantage from similar advances in control electronics, information and correspondence advances, and circulated vitality assets that drive organise changes in industrialised nations, enabling creating nations to enter a universe of smart miniaturised scale matrices, similarly as interchanges portable. they enabled them to associate with each one and the outdoor world without construction large settled line systems. "Half breed" smaller microgrids that consolidate sustainable power sources, frequently notwithstanding diesel-based frameworks, have extraordinary potential for differentiating generation and lessening the working expenses of miniaturised scale credit. island networks imported oil to deliver power and in territories remote from existing electrical framework. Remote smaller scale systems don't have to utilise a solitary way to deal with the framework plan; Through cautious asset appraisal and comprehension of interest profiles, undertakings can be streamlined by neighbourhood conditions. In any case, exceptional consideration must be given to the effect of asset changeability on the administration level, and besides, the support required to preserve the framework activity or to reestablish benefit in an incident of a generator disappointment. Cases of remote miniaturised scale organise examine Huatacondo Island in Chile, Xingxingxia in Xinjiang, China, and Lencois Island in Brazil. [18-22] [30-43] 


\section{Gyancity Journal of Electronics and Computer Science \\ Vol.3, No.1, pp. 11-23, March 2018 \\ ISSN:2446-2918 DOI: 10.21058/gjecs.2018.31002}

\section{CHALLENGES}

A. Absence of Community:

Duty One of the principal factors in charge of the disappointment of the small-scale arrange is the absence of association and connection with the network among the arranging period of the framework. Since the microgrid is intended for a network, it is important to include partners in the network to accomplish supportable vitality arranging and improvement. The gift of sustainable power source frameworks, for example, open lighting in light of photovoltaic vitality, water drawing frameworks to networks is regular in Nigeria, without an organised investment of the network in the upkeep of the frameworks. What's more, the land issue is an outstanding issue in a circumstance where there is no common understanding between organisers, engineers, agents or financial specialists, nor the legislature, nor the network.

\section{B. The absence of Education:}

There is an absence of learning of the ideal approach to utilise vitality. The most remote family units still utilise wasteful gadgets, the effects of which are for the most part not considered before the vitality framework is set up. What's more, the greater part of them don't get instruction on the most proficient method to ration vitality; for instance, apparatuses don't more often than not separate among the day, in a few houses when it isn't vital. The absence of training about the requirement for upkeep is another issue that adds to the disappointment of the smaller scale arrange in the nation. When all is said in done, sun based PV frameworks are for the most part considered as low upkeep vitality innovations. This is by and large misjudged and translated as a non-upkeep necessity such a significant number of PV frameworks in the nation come up short and are deserted a couple of years after establishment.

\section{Ownership:}

The greater part of the current sun-powered small scale matrices was given to rustic networks by government officials, as a rule for decision battles or to keep guarantees to add to their nearby supporters after the races. This training without a doubt builds the utilisation of sustainable power source frameworks yet does not ensure a reasonable vitality supply. One of the fundamental purposes behind this is the networks to which these frameworks are given don't expect responsibility for the foundation. In this circumstance, networks, for the most part, except that the obligation regarding working and keeping up the given frameworks will rely upon the givers. In this circumstance, networks, for the most part, except that the duty regarding working and keeping up the given frameworks will rely upon the givers. A comparable circumstance was likewise featured.

\section{Poor and Inappropriate Design:}

The outline, displaying, and arranging of sustainable power source microgrid $\mathrm{s}$ are unique about conventional fuel or diesel frameworks, the vast majority of which areas of now well-known. We have discovered that poor plan is one of the primary factors that decrease the necessary existence of microgrid s. The plan of sustainable power source frameworks includes a careful comprehension of accessible vitality assets and client request, and how changes in these can influence the accessibility or unwavering quality of vitality supply. A few originations are hopeful without considering the imagine a scenario where situation or more terrible. A case of such a situation is the expansion in clients' vitality utilization and its impact on the microgrid framework. For example, the photovoltaic generator won't give enough charging current to the battery. At the underlying phase of the microgrid framework, vitality creation seems, by all accounts, to be adequate for client request; be that as it may, after some time, the accessible power yield is lessened because of inadequate charge in the battery and the framework will in the long run fall flat when the battery's DoD achieves zero. The introduction of sunlight based PV modules is 


\section{Gyancity Journal of Electronics and Computer Science \\ Vol.3, No.1, pp. 11-23, March 2018 \\ ISSN:2446-2918 DOI: 10.21058/gjecs.2018.31002}

additionally imperative. A few sun based PV frameworks were not slanted at the required edge. These are among the specific issues and are ascribed to the absence of specialized skill in Nigeria.

\section{E. Poor Project Management:}

Best performs require that activities be very much managed by a skilled individual before being guaranteed \& charged. Frequently, ventures are left in the hands of temporary workers for establishment and supervision, so the nature of numerous undertakings is imperiled. The constrained supervision of smaller microgrids in the nation is one of the potential elements adding to its fall in the first years after execution.

\section{F. Absence of Financial Support by the Government:}

In most developed nations, administrations assume an essential part in supporting and advancing sustainable power source frameworks. One approach to accomplish this is money related help. This is absent in Nigeria and adds to the disappointment of the small-scale organise. Numerous people group are keen on embracing small microgrids. However, the absence of subsidising or vulnerabilities for money related help has impeded their plans and goals. As said over, a few government officials of smaller scale based PV have been given to the networks. Based on this assertion, networks don't take responsibility for matrices, and this brings up the issue of who bears the budgetary duty regarding dealing with the task and upkeep $(\mathrm{O}$ and $\mathrm{M})$ of smaller scale frameworks. This examination infers that there are a few measurements to the distinguished issue. Along these lines, the requirement for a multidimensional structure, for example, the STEEP model, which looks at the interrelated components that rise above the arranging system of conventional techno-financial vitality frameworks. Along these lines, in light of the MFF and SMF, top performs and practical knowledge, the Sustainable Planning Framework (SPF) is displayed in Figure 4, which abridges a portion of the variables or procedures that may comprehend the microgrid advancement.
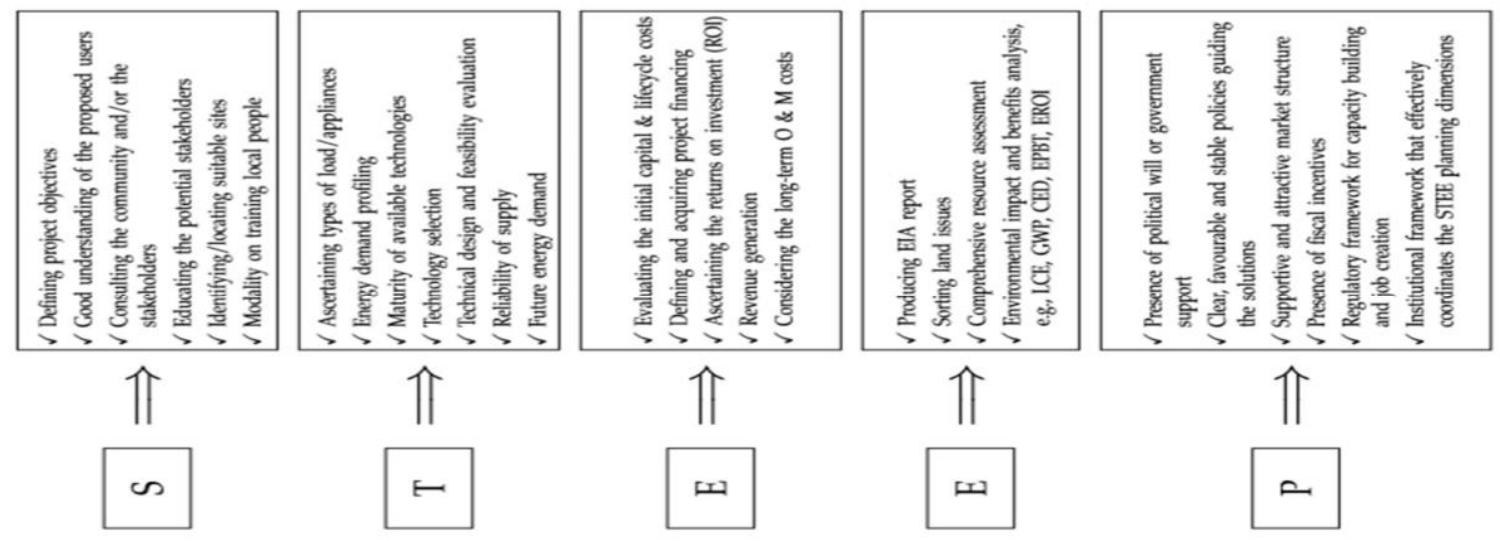

Fig. 4. Sustainable planning framework. [42]

A critical consideration of the leaders and partners is expected to plan the conceivable arrangements by first decoding the multi-faceted problems defined by the planned STEEP model, \& after that, settling to relieve them and encourage reasonable microgrid advancements in the nation. This is important to amend the harmful impress of the general population about sun-powered photovoltaic microgrids, to promote the enthusiasm for and utilisation of microgrids for rural electrification later on. Tending to the great test without any of the five component of the STEEP typical resources an inadequate arrangement. This is because every one of the measurements cooperates to accomplish the coveted manageable vitality improvement. For example, if the social (S) point of view isn't appropriately incorporated with the arrangement, it implies the rest of the part, i.e., the TEEP will have a mislaid connection between the partners, for example, the clients and the expected network, organisers, arrangement supplier or financier. In this way, the goals of the proposed vitality arrangements must be 


\section{Gyancity Journal of Electronics and Computer Science \\ Vol.3, No.1, pp. 11-23, March 2018 \\ ISSN:2446-2918 DOI: 10.21058/gjecs.2018.31002}

comprehended with sufficient contemplations for the planned clients. Besides, if the strategy (P) viewpoint, for example, isn't fittingly and satisfactorily careful in the arranging and improvement procedure, the rest of the part, i.e., the STEE, will undoubtedly come up short on account of the absence of powerful, steady or appropriate administrative structure. This is likewise the incident with each other measurement of the model, demonstrating the vitality of all the five principal components of the STEEP model. Beside the usage without bounds STEEP model for understanding the issue of microgrid dissatisfaction and the sensible factors in this paper, it can in like manner be used as the explanation behind working up a multi-criteria examination for picking essentialness progresses for remote systems. Our future work will consider the utilisation of the STEEP model for picking proper bound feasible power source system(s) for agricultural electrification purposes using the multi-criteria issue an examination approach. [38-43].

\section{MICHROGRIDS FUTURE}

It is additionally fascinating in this paper to exhibit the prospects for supportable small scale arrange innovations, particularly those in light of practical and financial applications [43-52]. In fact, the advantages of microgrid advancements go past household and local applications and can help enable clients and proposed networks. Urban/people group lighting frameworks with smaller scale grids lighting or remain only lighting frameworks can make nighttimenighttime business/business openings in the neighbourhood or remote networks. It enhances individuals' way of life as well as expands security around evening time. Other promising innovations for road lighting or road lighting, later on, are biodiesel, energy unit controlled motors and the little hydropower plant. Microgrid frameworks given half breed sustainable power source assets might be a fitting alternative for refrigeration and refrigeration/conservation of nourishments utilising vitality effective iceboxes. This will help limit the misuse of horticultural items and items, for example, angle, crab, foods grown from the ground benefits. Warm and biomass-based, sun based microgrids are a promising alternative for creating heat for farming procedures and families. Such a choice can enable spare to time in gathering kindling to develop warm vitality. Sun-powered photovoltaic, small microgrids can make business openings in remote networks, for example, cell phone charging stations, cybercafés, PCs and ICT focuses. This will decrease the time that inhabitants of remote systems need to the movement to different areas for the above administrations. Sunpowered photovoltaic smaller scale frameworks for water pumping are a promising choice for rural treatment and water system, including household applications. A water pump with biodiesel is a credible alternative for future needs.

\section{CONCLUSION}

The expression "Microgrid" is winding up increasingly normal in the present vitality designing engineering. It is as yet an idea in its early stages, yet it has incredible potential for particular offices and geographic impressions, for example, petrochemical plants, college grounds, mechanical parks that require solid vitality quality and army installations that require secure vitality supplies. Micromicrogrids will give enhanced electrical administration dependability and power quality for end clients, and can likewise profit nearby organisations by giving a delivery load to be utilised among crest periods and helping or deferring updates of the framework dispersion. There are many dynamic smaller scale microgrids extends far and wide that test and assess these progressed working ideas for control dispersion frameworks. As this short presentation has demonstrated that there should even now be some institutionalisation, "it's" what constitutes a Microgrid, although it is, for the most part, acknowledged that the capacity to "disconnect" and work outside the Microgrid is an operational base. When all is said in done, be that as it may, the Microgrid is by all accounts a chance to keep considering, creating pilot and exhibit ventures, and at last for more typical usage, maybe in light of Sandy and others. Catastrophic events The expenses of sun oriented photovoltaic power age and battery stockpiling are 


\section{Gyancity Journal of Electronics and Computer Science \\ Vol.3, No.1, pp. 11-23, March 2018 \\ ISSN:2446-2918 DOI: 10.21058/gjecs.2018.31002}

declining quickly, to the point of moving toward cost equality with conventional power sources. Subsequently, the across the board appropriation of these advances can rapidly quicken to the point where the vitality boycott, where end-clients import and fare power, is the standard and not the particular case. Before a massive number of conveyed vitality assets are associated with the framework, it is up to society to design and comprehend which engineering will best incorporate these energies and others innovations. Small-scale networks are set up to deal with this progress by adjusting free market activity at the neighbourhood level while guaranteeing consistent quality and versatility against what gives off an impression of being an expansion in common and human-made unsettling influences. Regardless of whether microgrids remain a speciality application or end up universal relies upon two primary components:

1 to what degree administrative and legitimate difficulties can be effectively surmounted

2 whether the esteem they convey to property proprietors and networks as far as power quality and dependability (QPR) \& extra monetary benefits exceed any cost premiums brought about to catch those benefits.

These inquiries are presently being replied in courts, and business showcases around the world as power networks advance to address social and financial concerns and consolidate 21 st-century innovation to refresh Thomas Edison's unique vision of the grids.

\section{ACKNOWLEDGEMENT}

The authors would like to dedicate this paper to His Parents, and Mr Atul Kumar, Student of M.S. College, Motihari, Bihar for their support and motivation to carry out this present work and our special thanks to Mr Dr Vishwajeet Pandey Chairman of Gyancity Research Lab, India for his valuable guidance and continuous encouragement to successfully completion of this work.

\section{REFERENCES}

[1] INTRODUCTION TO MICROGRIDS Ernie Hayden CISSP CEH Executive Consultant

[2] Johan Driesen And Farid Katiraei, “Design for Distributed Energy Resources,” IEEE PES May/June 2008.

[3] R.H.Lasseter,’Microgrids,” IEEE PES Winter Meeting, January 2002.

[4] Nikos Hatziargyriou,"Microgrids, the key to unlock distributed energy resources?," IEEE PES May/June 2008.

[5] AkoredeMF, HizamH, Pouresmaeil E.Distributed energy resources andbenefitsto the environment. Renew Sustain Energy Rev 2010;14:724-34. http://dx.doi.org/ 10.1016/j.rser.2009.10.025.

[6] Bayindir R, Hossain E, Kabalci E, Perez R. A comprehensive study on microgrid technology. Int J Renew Energy Res 2014;4:1094- 107.

[7] Abusharkh S, Arnold R, Kohler J, Li R, Markvart T, Ross J, et al. Can microgrids make a significant contribution to UK energy supply? Renew Sustain Energy Rev 2006;10:78-127. http://dx.doi.org/10.1016/j.rser.2004.09.013.

[8] Díaz-González F, Super A, Gomis-Bellmunt O, Villafáfila-Robles R. A review of energy storage technologies for wind power applications. Renew Sustain Energy Rev 2012;16:2154-71. http://dx.doi.org/10.1016/j.rser.2012.01.029.

[9] Kirubakaran A, Jain S, Nema RK. A review on fuel cell technologies and power electronic interface. Renew Sustain Energy Rev 2009;13:2430-40. http://dx.doi. org/10.1016/j.rser.2009.04.004.

[10] Mekhilef S, Saidur R, Safari A. Comparative study of different fuel cell technologies. Renew Sustain Energy Rev 2012;16:981-9. http://dx.doi.org/10.1016/j.rser. 2011.09.020.

[11] Neef HJ. An international overview of hydrogen and fuel cell research. Energy 2009;34:327-33.

[12] Mittal A., \& Agrawal, M. (2011). MICROGRID TECHNOLOGICAL ACTIVITIES ACROSS THE GLOBE: A REVIEW. International Journal of Research and Reviews in Applied Sciences, 147-152.

[13] Dohn, L. R., (2011). The business case for microgrids Whitepaper: The new face of energy modernisation,

[14] Ihamäki, J. (2012). INTEGRATION OF MICROGRIDS INTO ELECTRICITY DISTRIBUTION NETWORKS, Master Thesis, 115 pages. Lappeenranta University of Technology, Finland.

[15] Lidula, N.W.A \& Rajapakse, A.D. (2011). Microgrids research: A review of experimental microgrids and test systems. Renewable and Sustainable Energy Reviews, Volume 15, Issue 1, Pp186-202.

[16] Lasseter, R.H. (2007). Microgrids and Distributed Generation, Journal Of Energy Engineering, 133, 3, pp. 144-149, Academic Search Elite, EBSCOhost, viewed 7 December 2012.

[17] Higgins, N., Vyatkin, V., Nair, N.-K. \& Schwarz, K., (2010). Distributed Power System Automation with IEC 61850, IEC 61499 and 


\section{Gyancity Journal of Electronics and Computer Science \\ Vol.3, No.1, pp. 11-23, March 2018 \\ ISSN:2446-2918 DOI: 10.21058/gjecs.2018.31002}

Intelligent Control, Retrieved December 14, 2012, from The Net is Automation: http://www.nettedautomation.com/download/HVNS_SMC IEEE\%20final.pdf

[18] Ihamaki, J. (2011). FEASIBILITY STUDY OF THE AVAILABLE RELAY PROTECTION SOLUTIONS FOR MICRORIDS,

Bachelor Thesis, 25 pages. Lappeenranta University of Technology, Finland.

[19] Asmus, P. (2010). Microgrids, Virtual Power Plants and Our Distributed Energy Future. The Electricity Journal. 10406190. Elsevier Inc. Pp72-82

[20] Microgrids Soshinskaya, Mariya; Graus, Wina; Guerrero, Josep M.; Quintero, Juan Carlos VasquePublished in Renewable \& Sustainable Energy Review DOI (link to a publication from Publisher): 10.1016/j.rser.2014.07.198

[21] Hossain, E.; Kabalci, E.; Bayindir, R.; Perez, R. Microgrid testbeds around the world: state of the art. Energy Convers. Manag. 2014, 86, 132-153.

[22] Khodaei, A. Provisional microgrids. IEEE Trans. Smart Grids 2015, 6, 1107-1115.

[23] Chowdhury, S.; Chowdhury, S.P.; Crossley, P. MicrogridsandActiveDistributionNetworks; IET: Stevenage, UK, 2009.

[24] Lidula, N.W.A.; Rajapakse, A.D. Microgrids research: A review of experimental microgrids and test systems. Renew. Sustain. Energy Rev. 2011, 15, 186-202.

[25] Eid, B.M.; Rahim, N.A.; Selvaraj, J.; El Khateb, A.H. Control methods and objectives for electronically coupled distributed energy resources in microgrids: A review. IEEE Syst. J. 2016, 10, 446-458.

[26] 51. Jayasinghe, S.; Meegahapola, L.; Fernando, N.; Jin, Z.; Guerrero, J. Review of ship microgrids: System architectures, storage technologies and power quality aspects. Inventions 2017, 2, 4.

[27] Emmanuel, M.; Akinyele, D.; Rayudu, R. Techno-economic analysis of a ten kWp utility interactive photovoltaic system at Maungaraki school, Wellington, New Zealand. Energy 2017, 120, 573-583.

[28] Levron, Y.; Guerrero, J.M.; Beck, Y. Optimal power flow in microgrids with energy storage. IEEE Trans. Power Syst. 2013

[29] Poullikkas, A. Implementation of distributed generation technologies in isolated power systems. Renew. Sustain. Energy Rev. 2007, 11, 30-56.

[30] Ackermann, T.; Andersson, G.; Söder, L. Distributed generation: a definition. Electr. Power Syst. Res. 2001, 57, 195204.

[31] Zomers, A. The challenge of rural electrification. Energy Sustain. Dev. 2003, 7, 69-76.

[32] Foley, G. Rural electrification in the developing world. Energy Policy 1992, 20, 145-152.

[33] Shyu, C.W. Rural electrification program with renewable energy sources: Ananalysis of China's Township Electrification Program. Energy Policy 2012, 51, 842-853.

[34] Oyedepo, S.O. Towards achieving energy for sustainable development in Nigeria. Renew. Sustain. Energy Rev. 2014

[35] Oyedepo, S.O. On power for sustainable development in Nigeria. Renew. Sustain. Energy Rev. 2012, 16, 2583-2598.

[36] Challenges of Microgrids in Remote Communities: A STEEP Model Application, () 2018 by the authors. Licensee MDPI, Basel, Switzerland

[37] Cooperative Synchronization in Distributed Microgrid Control, ISBN 978-3-319-50807-8

[38] INTRODUCTION TO MICROGRIDS Ernie Hayden CISSP CEH

[39] INTERNATIONAL JOURNAL OF RENEWABLE ENERGY RESEARCH Ramazan Bayindir et al. , Vol. 4, No. 4, 2014 A Comprehensive Study on Microgrid Technology

[40] Microgrids: A Review of Technologies, Key Drivers, and Outstanding Issues, Article in Renewable and Sustainable Energy Reviews · April 2018

[41] Microgrids Soshinskaya, Mariya; Graus, Wina; Guerrero, Josep M.; Quintero, Juan Carlos Vasquez Published in Renewable \& Sustainable Energy Reviews DOI (link to a publication from Publisher): 10.1016/j.rser.2014.07.198 Aalborg Universtet

[42] A Review of Recent Developments in Micro Grid, International Refereed Journal of Engineering and Science (IRJES) e- ISSN: 2319183X p-ISSN: 2319-1821

[43] Seifi, M.; Soh, A.C.; Wahab, N.I.A.; Hassan, M.K. Modeling of PV standalone microgrid based on IEEE standards, 1562-2007, 1361- 2003 and 1013-2007. Rev. Model. Simul. 2013, 6, 515-525.

[44] IEEE Guide for Selecting, Charging, Testing, and Evaluating Lead-Acid Batteries Used in Stand-Alone Photovoltaic (PV) Systems; IEEE Std 1361-2014; IEEE: New York, NY, USA, 2014; ISBN 978-0-7381-9172-0.

[45] Arndt, R.; Puto, R. Basic Understanding of IEC Standard Testing for Photovoltaic Panels; Technical Report; TÜV SÜD America Inc.: Peabody, MA, USA, 2010.

[46] Foley, G. Rural electrification in the developing world. Energy Policy 1992, 20, 145-152.

[47] Akuru, U.B.; Onukwube, I.E., Okoro, O.I.; Obe, E.S. Towards 100\% renewable energy in Nigeria. Renew. Sustain. Energy Rev. 2017, 71, 943-953

[48] Gollwitzer, L. Community-Based Micro Grids: A Common Property Resource Problem; Technical Report; STEPS Centre: Brighton, UK, 2014. 


\section{Gyancity Journal of Electronics and Computer Science \\ Vol.3, No.1, pp. 11-23, March 2018 \\ ISSN:2446-2918 DOI: 10.21058/gjecs.2018.31002}

[49] Zalengera, C; Blanchard, R.E.; Eames, P.C.; Juma, A.M.; Chitawo, M.L.; Gondwe, K.T. Overview of the Malawi energy situation and A PESTLE analysis for the sustainable development of renewable energy. Renew. Sustain. Energy Rev. 2014,

[50] Chaurey, A.; Kandpal, T.C. A techno-economic comparison of rural electrification based on solar home systems and PV microgrids. Energy Policy 2010, 38, 3118-3129.

[51] Jha, S.K.; Stoa, P.; Uhlen, K. Microgrid: Prospects and challenges in Nepal. In Proceedings of the Power and Energy Systems Conference: Towards Sustainable Energy, Bangalore, India, 13-15 March 2014.

[52] Adeleke, A.A. Sustainability of solar mini-grids in Nigeria. Master's Thesis, University of Ibadan, Ibadan, Nigeria, 2016 